\title{
The Legal Construction of Sharia Capital Market in Indonesia
}

\author{
Elsy Renie ${ }^{1} \quad$ Thohir Luth $^{2} \quad$ Siti Hamidah $^{3}$ Sihabbudin ${ }^{4}$ \\ 1.Candidate of Doctor in the Faculty of Law, Brawijaya University, Indonesia \\ Jl. M.T. Haryono No. 169, Ketawanggede, Kec. Lowokwaru, Kota Malang, Jawa Timur 65145 \\ 2.Professor of Law, Faculty of Law, Brawijaya University, Indonesia \\ Jl. M.T. Haryono No. 169, Ketawanggede, Kec. Lowokwaru, Kota Malang, Jawa Timur 65145 \\ 3.Associate Professor Faculty of Law, Brawijaya University, Indonesia.. \\ M.T. Haryono No. 169, Ketawanggede, Kec. Lowokwaru, Kota Malang, Jawa Timur 65145 \\ 4.Associate Professor, Faculty of Law, Brawijaya University, Indonesia. \\ Jl. M.T. Haryono No. 169, Ketawanggede, Kec. Lowokwaru, Kota Malang, Jawa Timur 65145
}

\begin{abstract}
Capital market is one of the characteristics of developed countries, but its activities in Indonesia experience ups and downs. The Islamization of financial institutions in Indonesia was responded by the country's capital market in 1997. Islamic capital market has developed following Islamic banking and Islamic insurance industry. The importance of asset management and liquidity management in these two industries raises the need for sharia-based funding sources and investment products, which encourages the development of sharia capital market activities. The beginning of sharia capital operations was the sale of Indosat shares using sharia system in 2012. Law number 8 of 1995 concerning capital market does not explain the dual system in the Indonesian capital market. The legal vacuum that regulates capital market activities has led to an MOU signed in 2003 between BAPEPAM and National Sharia Board-Indonesian Ulema Council (DSN-MUI), an institution established to provide solutions and fatwas on economic development and sharia financial institutions in Indonesia. This step is a good momentum for the development of the legal framework of the Indonesian capital market because several DSN-MUI fatwas have been absorbed into the financial services authority regulations issued by the OJK. This normative research uses a legal approach (statute approach). The researchers conclude that regulations regarding Islamic capital market since its operations in the Indonesian capital market have developed. But higher norms that govern Islamic capital market are needed so that the existence of the Islamic capital market in Indonesia can be maintained, and justice and legal certainty for Islamic capital market players can be achieved.
\end{abstract}

Keywords: Capital market, Islamic capital market, DSN-MUI fatwas

DOI: $10.7176 / \mathrm{JLPG} / 82-05$

\section{Introduction}

The existence of capital market in Indonesia is one of the most important factors in building national economy. In fact, capital market has become the financial nerve center of the current modern world economy, which is impossible to exist without a strong, globally organized, and well-organized capital market.

Amid the deterioration national economic growth, which also affect capital market sector as a subsystem of the Indonesian national economy, Indonesian capital market industry has begun to look at the development of the application of Islamic sharia principles as an alternate investment instrument in capital market activities in Indonesia.

The rise of the Islamic economy in Indonesia today is an interesting and exciting phenomenon, especially for Indonesians, who are mostly Muslims. The practice of conventional economic activities, especially in capital market activities that contain elements of speculation as one of its components, still seems to be a psychological obstacle for Muslims to be involved in investment activities, especially in the capital market. The general difference between the conventional capital market and the Islamic capital market is in the instruments and mechanism of transactions and the stock index values.

The construction of Islamic capital market law in accordance with Islamic law is needed because the legal norms governing capital market are still weak in upholding Islamic principles and the philosophical values of Islamic economics, both in products, mechanisms, supporting institutions, supporting professions, supervision, and other matters related to capital market activities. Changes to the capital market law, adoption of norms regarding sharia securities issuance, and other matters relating to sharia capital market activities are efforts to carry out Islamic capital market activities with legal strength and certainty, so that Islamic capital market is not forced to use rules that is his identity.

\section{Research Problem}

What is the urgency of the legal construction for Islamic capital market in Indonesia? 


\section{Discussion}

\subsection{The Legal Aspect of Sharia Capital Market}

Indonesia is a country upholding Pancasila philosophy that recognizes the existence of God. Pancasila is the foundation of the state and the source of all sources of law, so any rule of law must be based on Pancasila. Recognition of religions and believes in God Almighty and protection for the citizens to embrace a religion and to worship God on the basis of their religion and belief are characteristics of a country that believes in the Almighty. Thus, Indonesia is not a religious country because it is not based on a particular religion, nor is it a secular state because it does not separate religious affairs from the state.

The legal basis of Islamic economics (Amran Suardi, 2016, pp. 424) is Pancasila, the foundation of the state. The 1945 Constitution article 29 Paragraph 1 states that "Indonesia is based on the One God", and paragraph 2 states that "The state guarantees the independence of each citizens to embrace their religion and to worship God according to their religion and belief." Thus, the government is obliged to regulate religious life in Indonesia.

Furthermore, the idea of economic democracy is stated in the explanation of the 1945 Constitution and the 1945 Constitution article 33 paragraph (4) after amendment. The 1945 Constitution explicitly contains the idea of political democracy as well as economic democracy, which means that the holders of the highest authority in Indonesia are the people, in both politics and economics. Economics requires a normative foundation so that its strategies, policies, and programs are well directed. The normative foundation of the Indonesian economic system is Article 33 of the 1945 Constitution. This article has changed and developed after the amendment. Article 33 paragraph (1) of the 1945 Constitution states that the economy is structured as a joint effort based on the kinship principles. The article formulated by the founding fathers has a nuance of socialism with familial and collective spirit rather than competition. However, it does not rule out the possibility of implementing Islamic economic system. Paragraph 4 states that the national economy is held based on economic democracy with the principle of togetherness, fairness, sustainability, environmental insight, and independence while maintaining the balance of national economy, progression, and unity (Reka Dewantara, 2014)

The foundation has opened up opportunities for the development of Islamic capital market in Indonesia, as well as the adoption of Islamic law into the Indonesian legal system. Done since Dutch colonialism, adoption was not something new. Indeed, the absorption of Islamic law into the national legal system has increasingly become apparent since the independence of the state, such as Law Number 1 of 1974 concerning Marriage (Law 1/1974), Law Number 41 of 2004 concerning Waqf, Law Number 19 of 2008 concerning State Sharia Securities, Law Number 21 of 2008 concerning Sharia Banking, Law Number 23 of 2011 concerning Management of Zakat, Presidential Instruction Number 1 of 1991 concerning Dissemination of Compilation of Islamic Law, and Supreme Court Regulation Number 2 of 2008 concerning Compilation of Sharia Economic Law. In addition, the revised limited liability company law in 2007 made DPS explicit in the company that runs its business based on sharia law. Furthermore, the absorption of Islamic law that is private in Indonesia is more easily accommodated into national regulations than Islamic law in other fields.

The regulations relating to the current Indonesian Islamic capital market are issued by the Financial Services Authority (OJK) in the form of government regulations, directly in the form of laws and supporting regulations. Specifically, for OJK regulations, there are currently 10 regulations regarding the Islamic capital market as follows:

\begin{tabular}{|c|c|c|}
\hline NO. & TITLE & EXPLANATION \\
\hline 1 & $\begin{array}{l}\text { Laws and } \\
\text { Regulation }\end{array}$ & $\begin{array}{l}\text { 1. Law No. } 8 \text { of } 1995 \text { concerning the capital market } \\
\text { 2. Law No. } 19 \text { of } 2008 \text { concerning State Sharia Securities } \\
\text { 3. Government Regulation of the Republic of Indonesia Number } 45 \text { of } 1995 \\
\text { concerning the activities in the capital market } \\
\text { 4. Government Regulation of the Republic of Indonesia Number } 56 \text { of } 2008 \\
\text { concerning state sharia securities issuing companies } \\
\text { 5. Government Regulation of the Republic of Indonesia Number } 56 \text { of } 2011 \\
\text { concerning project financing through the issuance of state sharia securities }\end{array}$ \\
\hline 2 & $\begin{array}{l}\text { Regulations } \\
\text { of } \\
\text { BAPEPAM } \\
\text { LK }\end{array}$ & $\begin{array}{l}\text { a. Regulation Number II.K.1: The criteria and the issuance of sharia securities list } \\
\text { b. BAPEPAM LK Regulation No. IX.A.13 concerning the issuance of sharia } \\
\text { securities }\end{array}$ \\
\hline
\end{tabular}




\begin{tabular}{|c|c|c|}
\hline NO. & TITLE & EXPLANATION \\
\hline 3 & $\begin{array}{l}\text { Regulations } \\
\text { of } \\
\text { Indonesian } \\
\text { Financial } \\
\text { Services } \\
\text { Authority } \\
\text { (OJK) }\end{array}$ & $\begin{array}{l}\text { a. Regulation of the Financial Services Authority Number 15 / Pojk.04 / } 2015 \\
\text { concerning the application of sharia principles in the capital market } \\
\text { b. Regulation of the Financial Services Authority Number } 16 \text { / Pojk.04 / } 2015 \\
\text { concerning sharia experts of capital market } \\
\text { c. Regulation of the Financial Services Authority Number } 17 \text { / Pojk.04 / } 2015 \\
\text { concerning the issuance and requirements of sharia securities in the form of } \\
\text { shares by Islamic issuers or sharia public companies } \\
\text { d. Regulation of the Financial Services Authority } 18 \text { / Pojk.04 / } 2015 \text { concerning } \\
\text { the issuance and requirements of sukuk } \\
\text { e. Regulation of the Financial Services Authority Number } 19 \text { / Pojk.04 / } 2015 \\
\text { concerning the issuance and requirements of sharia mutual funds } \\
\text { f. Regulation of the Financial Services Authority Number } 20 \text { / Pojk.04 / } 2015 \\
\text { concerning the issuance and requirements of Sharia-backed assets } \\
\text { g. Financial Services Authority Regulation Number 30/Pojk.04 / 2016 concerning } \\
\text { Collective Investment Funds (Sharia DIRE) } \\
\text { h. Regulation of the Financial Services Authority Number 53 / Pojk.04/2015 } \\
\text { concerning contracts used in the issuance of Islamic securities in capital market } \\
\text { i. Regulation of the Financial Services Authority Number } 61 \text { / Pojk.04/2016 } \\
\text { concerning the application of sharia principles in capital market for investment } \\
\text { managers }\end{array}$ \\
\hline 4 & $\begin{array}{l}\text { The Fatwa } \\
\text { of the } \\
\text { National } \\
\text { Sharia } \\
\text { Board of } \\
\text { Indonesian } \\
\text { Ulemma } \\
\text { Council } \\
\text { (DSN } \\
\text { MUI) }\end{array}$ & $\begin{array}{l}\text { a. Fatwa Number } 80 \text { / DSNMUI / III / } 2011 \text { concerning the application of sharia } \\
\text { principles in the mechanism of equity securities trading in the regular stock } \\
\text { exchange market } \\
\text { b. Fatwa Number } 76 \text { / DSN-MUI / VI / } 2010 \text { concerning SBSN Ijarah Asset to be } \\
\text { Leased } \\
\text { c. Fatwa Number } 72 \text { / DSN-MUI / VI / } 2008 \text { concerning State Sharia Securities } \\
\text { ijarah sale and lease back } \\
\text { d. Fatwa Number } 71 \text { / DSN-MUI / VI / } 2008 \text { concerning sale and lease back } \\
\text { e. Fatwa Number } 70 \text { / DSN-MUI / VI / } 2008 \text { concerning issuance method of State } \\
\text { f. Sharia Securities } \\
\text { g. Fatwa Number: } 69 \text { / DSN-MUI / VI / } 2008 \text { concerning State Sharia Securities } \\
\text { h. Fatwa Number } 65 \text { / DSN-MUI / III / } 2008 \text { concerning sharia pre-emptive rights } \\
\text { i. Fatwa Number } 59 \text { / DSN-MUI / V / } 2007 \text { concerning convertible mudharabah } \\
\text { sharia bonds } \\
\text { j. Fatwa of the National Sharia Board Number } 20 \text { / DSN-MUI / IV / } 2001 \\
\text { concerning guidelines for Investing in sharia mutual funds } \\
\text { k. Fatwa of the National Sharia Board Number: } 32 \text { / DSN-MUI / IX / } 2002 \\
\text { concerning sharia bonds } \\
\text { 1. Fatwa of the National Sharia Board Number } 40 \text { / DSN-MUI / IX / } 2003 \\
\text { concerning capital markets and general guidelines for the implementation of } \\
\text { sharia principles in the capital market } \\
\text { m. Fatwa of National Sharia Board Number } 41 \text { / DSN-MUI / III / } 2004 \text { concerning } \\
\text { ijarah sharia bonds } \\
\text { n. Fatwa of the National Sharia Board Number: } 65 \text { / DSN-MUI / III / } 2008 \\
\text { concerning sharia pre-emptive rights } \\
\text { o. Fatwa of the National Sharia Board Number } 66 \text { / DSN-MUI / III / } 2008 \\
\text { p. Fatwa of the National Sharia Board Number: } 95 \text { / DSN-MUI / VII / } 2014 \\
\text { concerning State Sharia Securities wakalah } \\
\text { sharia mudharabah bonds }\end{array}$ \\
\hline
\end{tabular}

Based on the table above, the Indonesian capital market is regulated in Law No. 8 of 1995. This law has not adopted a dual system of capital markets so that there are no norms that regulate the Islamic capital market. The implementation of Islamic capital market activities in Indonesia is inseparable from the role of DSN-MUI, so in 2003 the MOU between BAPEPAM and DSN-MUI was signed as a form of coordinative cooperation, given the legal vacuum regarding Indonesian capital market activities. In 2012 BAPEPAM, which is a capital market supervisory institution based on Law no. 8 of 1995 concerning the capital market, issued two regulations governing 
the criteria and issuance of sharia securities. In 2015, since supervision on financial institutions was taken over by the Financial Services Authority under Law No. 21 of 2011 concerning OJK, ten regulations related to sharia capital market activities in Indonesia are issued by OJK. These regulations regulate sharia capital market activities that adopt the DSN-MUI fatwas. Until now, the DSN-MUI has issued 18 fatwas to regulate capital market activities. Fatwa of DSN MUI is based on Indonesian law, not a source of law in the hierarchy of laws and regulations. Thus, the fatwa needs to be integrated into BAPEPAM regulations. In the next process, BAPEPAM and LK (now OJK) synchronize and harmonize the fatwa into OJK rules through new rules or revisions of old rules. Regulations related to the Islamic capital market are first issued by BAPEPAM in 2006, namely Regulation Number IX.A.13 concerning Sharia Securities Issuance and Rule Number IX.A.14 concerning contracts used in issuing Islamic securities. In 2007 Rule Number II.K.1 concerning Criteria and Issuance of List of Sharia Securities was issued. With the development of the Islamic capital market, Rule Number IX.A.13 and Rule Number IX.A.14 were refined in 2009, while Rule Number II.K.1 was also improved in 2012. Thus, the development of regulations related to Islamic capital market activities in Indonesia can be classified by period. This, according to the author, also shows the development of the legal politics of Islamic economics:
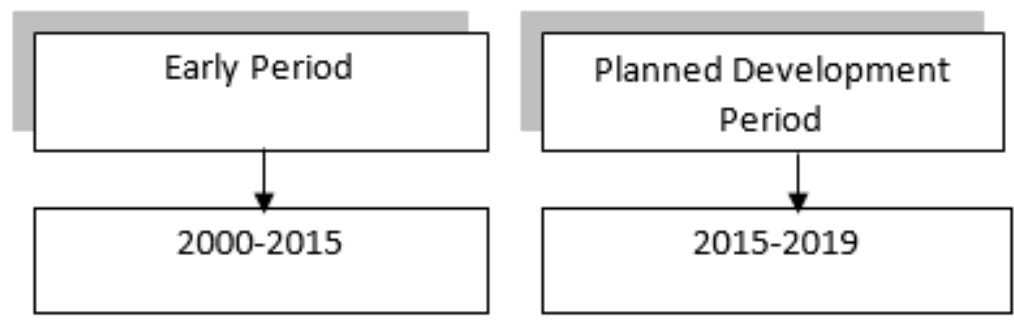

The initial period of the Islamic capital market in Indonesia was started with the issuance of Sharia Mutual Funds by PT. Danareksa Investment Management on July 3, 1997. Furthermore, the Indonesia Stock Exchange (previously known as the Jakarta Stock Exchange) cooperated with PT. Danareksa Investment Management launched the Jakarta Islamic Index on July 3, 2000, which aims to guide investors who want to invest their funds according to sharia law. The presence of the index provides investors with stock-shares to invest in accordance with sharia principles. At that time the MUI had just initiated the formation of a division specifically dealing with issues related to the activities of sharia financial institutions (LKS). After its official issuance in 1999, the National Sharia Board of the Indonesian Ulema Council (DSN-MUI) issued a fatwa directly related to the capital market for the first time on April 18, 2001, namely Fatwa Number 20 / DSN-MUI / IV / 2001 concerning Guidelines for Implementation of Investment for Sharia Mutual Funds. Furthermore, Islamic investment instruments in the capital market continue to grow with the presence of Syariah Bonds PT. Indosat Tbk at the beginning of September 2002. This instrument is the first sharia bond, and the contract used is the mudharabah contract. The issuance of Islamic bonds by Indosat is a very important momentum in the course of the history of the Islamic capital market in Indonesia, where the MoU between BAPEPAM and DSN-MUI was signed on March 14, 2003. The MoU shows an understanding between BAPEPAM and DSN-MUI to develop the market sharia-based capital in Indonesia. The author sees that this MoU is an acknowledgment of the DSN to make the DSN-MUI fatwa a material source, given the legal vacuum related to the Islamic capital market activities in Indonesia. In this initial period, there were two BAPEPAM regulations related to sharia capital market activities that adopted the fatwa of DSN-MUI. In 2004 the development of the Islamic capital market was incorporated into the organizational structure of BAPEPAM and LK, carried out by echelon IV level units specifically assigned to develop the Islamic capital market. The development of the Islamic capital market reached a new milestone with the passing of Law Number 19 of 2008 concerning State Sharia Securities (SBSN). This law is required as a legal basis for the issuance of State Sharia Securities or state sukuk. Although the issuance of State Sharia Securities already has clear rules, issuance of equity and other matters still needs to be explored, considering that the capital market system is a capitalist system that tries to apply sharia principles.

In planned development, the Islamic capital market has made a lot of progress. At this time, the supervisory duties of BAPEPAM-LK have been replaced by the Financial Services Authority (OJK). Starting in 2015, the OJK issued a clear roadmap for the development of the Indonesian Islamic capital market. In the same year OJK issued five regulations related to sharia capital market activities which were adapted from fatwas of DSN-MUI. Until now, OJK has issued 10 regulations regarding the sharia capital market activities. These regulations are sourced from the DSN-MUI fatwas.

\subsection{The Pattern of Dual System Arrangement in Indonesian Capital Market}

Agus Triyanta (2004) reveals that the emergence of the Islamic capital market is not only a place to invest for Muslims who adhere to the prohibition of the flower system but also the opportunity to build alternative economic systems. Some things that must be considered in the effort to enforce sharia compliance are standardization of 
contracts, transparency of sharia accounting, and reorientation of investment objectives. Andri Sumitra, in his research on the future of the Islamic capital market in Indonesia, uses the approach of sharia product integration in the national capital market which is still dominated by conventional systems and structures that do have a number of advantages, weaknesses, opportunities and challenges (Andri Sumitra, 2015, pp. 351). The same thing was also expressed by Baharuddi Susamto. The solution to the Islamization of this company is very important to emphasize that Islamic principles can be applied to modern companies through an integration approach. But researchers have different arguments with some previous researchers, that the Islamic capital market requires a new rule that has legal certainty, given the epistemological differences between Islamic and conventional capital markets. For the legal framework of Islamic capital market that is in accordance with Islamic economic goals and philosophical values that animates it, it needs to be developed, not only the sub-system of capitalists that seeks to be Islamic, as analyzed by Robert W. Hefner about the phenomenon of the emergence of sharia financial institutions in Indonesia (Ricardh W. Hefner, 2003, pp. 19)

Contemporary Islamic economics is compiled by adhering to the rule of game of sharia and modern scientific principles. Islamic values are a source of information and guidance in the process of developing science, so that the ontological, epistemological, and axiological aspects are always within the corridor of Islam. Ontologically, Islamic economics discusses two disciplines simultaneously. The two disciplines are pure economics and the science of fiqh muammalat. Thus, in the operation of Islamic economics will always be sourced from these two disciplines. The ontological problem that arises later is how to integrate economic science thinking with fiqh thought contained in fiqh muammalat. This problem arises because the source of Islamic economics is human thought, while the source of fiqh muammalat is a revelation based on the Koran and Hadith. This difference in sources of knowledge causes differences in the assessment of economic problems of humans.

The Islamic capital market also has key principles that must be adhered to before designing Islamic financial institutions, namely the prohibition on usury, gharar, maisir, bay'u Inah, (Simon And Rifaat Ahmed, 2018, pp. 13). According to M.M Matewally (1984, pp. 24) the existence of the Islamic capital market, in addition to carrying out the functions of the capital market, provides other benefits for the national economy, namely:

a. It is possible for people to participate in business activities by obtaining a share of the benefits and risks.

b. Allows shareholders to sell their shares to get liquidity.

c. Enables companies to increase capital from outside to build and develop their production lines.

d. Separating business operations from short-term fluctuations in stock prices, which are a common feature of conventional capital markets.

e. Enables investment in the economy that is determined by the performance of business activities as reflected in stock prices.

\subsection{The Importance of Sharia Capital Market Regulation Development}

According to Satjipto Rahardjo, the law is not made in a vacuum. Law is born from the provisions that live in society (ibi societas ibi ius) (Satjipto, 2004). Article 5 and 6 of Law Number 12 of 2011 concerning the Establishment of Legislation (Law 12/2011) regulates the requirements of legal principles that must always be in a legal rule. To realize a sharia capital market that has legal certainty, the principle of legal certainty must not cause doubt (multi-interpretation). It must be logical in the sense of being a norm system that does not clash with other norms due to uncertainty. In order to avoid obscurity in interpreting the prevailing rules, efforts to establish a strong legal framework for sharia capital markets in national legal arrangements are necessary.

In terms of the time of enactment, the law is divided into two parts: ius constitutum, i.e. the law that is now being applied, and ius constituendum, namely the law that will be applied in the future. The process of sharia capital market legal construction in the legal system in Indonesia can be assessed by placing it as ius constitutum and ius constituendum. Ius constitutum means how the construction process of the regulation of the Islamic capital market is now valid. Ius constituendum means how the sharia capital market provisions based on DSN-MUI fatwa can be a separate Law in the future, as in Sharia Banking which initially followed conventional banking laws and later has its own laws.

According to Padmo Wahyono, the law that will apply in society is the law adopted by the majority of the people. In the Indonesian context, all legal ideas must be in the frame of Pancasila. Through Pancasila, without mentioning too much Islamic logocentrism, the majority law is very prospective to take effect. The mission and theme are always in order to support the foundation and strengthen the nation building structure based on Pancasila (Muhammad M. Nur Yasin, 2018, p. 156)

Soerjono Soekanto and Purnadi Purbacaraka also explained that Ius Constituendum changed to ius constitutum in the following way (Soerjono Soekanto, 1994. pp. 7).

a. Replacing a law with a new law (the new law was originally a draft ius constituendum).

b. Change existing laws by incorporating new elements (new elements at first in the form of ius constituendum).

c. Interpreting legislation. In current times interpretation may not be the same as interpretation in the past. 
The interpretation in current times was ius constituendum.

d. Developing doctrines or opinions of leading legal scholars in the field of legal theory.

Islamic economics is based on Islamic epistemology because it relates to the worldview of Islam itself. This is in line with what Aslam Haneef revealed that Islamic economics needs to be developed, implemented, and evaluated through concepts, sizes, and standards as "Islamic framework" products involving worldview and Islamic philosophy based on the worldview of Islam. (Aslam Haneef, 2005, pp. 46-47)

The uniqueness of the Islamic financial system lies in its philosophical foundation that goes beyond the interaction of factors of production and economic behavior. The Islamic financial system balances the ethical, moral, social, economic and ideological aspects of religion to improve equality and justice for the good of the whole community (Zamir Iqbal, pp. 13-24)

The construction of Islamic capital market law in accordance with Islamic law needs to be built because the legal norms governing the current Islamic capital market are considered weak in upholding sharia principles and philosophical values of Islamic economics, both in terms of products, mechanisms, institutions supporting, supporting professions, supervision and other matters related to capital market activities.

Changes to the capital market law and the issuance of norms regarding the issuance of sharia securities and other matters relating to sharia capital market activities are efforts to carry out sharia capital market activities that have the power and legal certainty in Indonesia. Therefore, the Islamic capital market is not forced to use rules that are not their identity.

\section{Conclusion}

Islamic economics is based on Islamic epistemology because it relates to the worldview of Islam itself . The construction of Islamic capital market law in accordance with Islamic law needs to be built because the legal norms governing the current Islamic capital market are considered weak in upholding sharia principles and philosophical values of Islamic economics, both in terms of products, mechanisms, institutions supporting, supporting professions, supervision and other matters related to capital market activities. The construction of sharia capital market law in the future must provide legal certainty in the issuance of shares, screening processes, market systems, assessment of sharia compliance that is guided by the fatwa of DSN-MUI adapted from the books of fiqh muammalat.

\section{Reference}

Muhammad M. Nur Yasin. (2018), Politik Hukum Ekonomi Islam di Indonesia, UIN Maliki Press, Soerjono Soekanto dan Purnadi Purbacaraka. (1994), Aneka Cara Pembedaan Hukum. Bandung: PT Citra Aditya Bakti.,

Kattsoff, Louis O. (1992). Pengantar Filsafat. Yogyakarta: Tiara Wacana Yogya.

Haneef, Aslam, “Islamisasi Ilmu Ekonomi: Apa yang Salah?” Majalah Pemikiran Dan Peradaban Islam, ISLAMIA. Jakarta. No.6 Juli-september 2005

Zamir Iqbal, "Islamic Financial Systems" dalam seminat proceeding on Islamic Banking and Finance : Contempaorary Issue No. 47

Andri Sumitra, (2015) Masa depan pasar modal Syariah di Indonesia, Jakarta,

Agus Triyanta, (2004), Menegakkan Syariah Compliance dalam Pasar Modal Syariah, Jurnal Hukum. No. 25. Vol 11. Januari

Ricardh w. Hefner, (2003), Islamizing Capitalism, from, Shari'a and Politics in Modern Muslim Indonesia, Singapore, institute of Southeast Asian Studies.

Budioyono, (2014), Hubungan Negara Dan Agama Dalam Negara Pancasila, Fiat Justitia jurnal ilmu hukum volume 8

Amran Suardi dan Mardi Candra, (2016)Politik Hukum Perspektif Hukum perdata dan Pidana Islam serta Ekonomi Syariah, Jakarta: Kencana,

Reka Dewantara, (2016), Rekonseptualisasi Asas Demokrasi Ekonomi Dalam Konstitusi Indonesia, Arena Hukum Volume 7, Nomor 2, Agustus 201

Mochtar M. Metwally, (1984) The Role of The stock Exchange in an Isamic Economy, J. Res. Islamic Econ., Vol. 2, No. 1, pp. 19-28

Budiartha, N.Y. (2016). Konsep Alih daya, Bentuk Perlindungan, dan Kepastian Hukum, Hukum Outsourcing. Malang: Setara Press. 